\title{
Identification of Clusters from Reactions of Ruthenium Arene Anticancer Complex with Glutathione Using Nanoscale Liquid Chromatography Fourier Transform Ion Cyclotron Mass Spectrometry Combined with ${ }^{18} \mathrm{O}$-Labeling
}

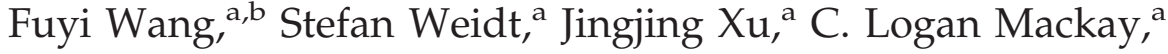 \\ Pat R. R. Langridge-Smith, ${ }^{a}$ and Peter J. Sadler ${ }^{\mathrm{a}, \mathrm{c}}$ \\ a School of Chemistry, University of Edinburgh, Edinburgh, United Kingdom \\ ${ }^{\mathrm{b}}$ Institute of Chemistry, Chinese Academy of Sciences, Beijing, China \\ ${ }^{\mathrm{c}}$ Department of Chemistry, University of Warwick, Coventry, United Kingdom
}

Reactions of the anticancer complex $\left[\left(\eta^{6}-\mathrm{bip}\right) \mathrm{Ru}(\mathrm{en}) \mathrm{Cl}\right]^{+}$(where bip is biphenyl and en is ethylenediamine) with the tripeptide glutathione ( $\gamma$-L-Glu-L-Cys-Gly; GSH), the abundant intracellular thiol, in aqueous solution give rise to two ruthenium cluster complexes, which could not be identified by electrospray mass spectrometry (ESI-MS) using a quadrupole mass analyzer. Here we use Fourier transform ion cyclotron mass spectrometry (nanoLC-FT-ICR MS) to identify the clusters separated by nanoscale liquid chromatography as the tetranuclear complex $\left[\left\{\left(\eta^{6}-\mathrm{bip}\right) \mathrm{Ru}\left(\mathrm{GSO}_{2}\right)\right\}_{4}\right]^{2-}$ (2) and dinuclear complex $\left[\left\{\left(\eta^{6}-\text { bip }\right) \mathrm{Ru}\left(\mathrm{GSO}_{2}\right)_{2}\right\}_{2}\right]^{8-}$ (3) containing glutathione sulfinate $\left(\mathrm{GSO}_{2}\right)$ ligands. Use of ${ }^{18} \mathrm{OH}_{2}$ showed that oxygen from water can readily be incorporated into the oxidized glutathione ligands. These data illustrate the power of high-resolution MS for identifying highly charged multinuclear complexes and elucidating novel reaction pathways for metallodrugs, including ligand-based redox reactions. (J Am Soc Mass Spectrom 2008, 19, 544-549) @ 2008 American Society for Mass Spectrometry

C omplexes of the second row, group 8 transition-metal ruthenium are of medical interest. Two $\mathrm{Ru}^{\mathrm{III}}$ complexes are currently undergoing clinical trials as anti-cancer agents, and $\mathrm{Ru}^{\mathrm{II}}$ arene complexes have shown promising activity in model cancer systems [1]. Ruthenium has seven isotopes, making the mass isotopic pattern of ion peaks of ruthenium-containing compounds characteristic, yet complicated [2-6]. In our previous work [2, 3, 7-9], mass spectra acquired by electrospray ionization (ESI-MS) equipped with a quadrupole mass analyzer allowed unambiguous assignment of singly charged ion peaks of mononuclear ruthenium arene complexes as well as their adducts with amino acids, peptides, and DNA. However, low-resolution ESI-Q MS was unable to identify two multinuclear ruthenium clusters, which arose from the reaction of the

Address reprint requests to Professor P. J. Sadler, Department of Chemistry, University of Warwick, Coventry CV4 7AL, UK. E-mail: P.J.Sadler@warwick.ac.uk ruthenium arene anticancer complex $\left[\left(\eta^{6}\right.\right.$-bip $) \mathrm{Ru}-$ $(\mathrm{en}) \mathrm{Cl}]^{+}$(where bip is biphenyl and en is ethylenediamine) with the tripeptide glutathione ( $\gamma$-L-Glu-LCys-Gly; GSH) in aqueous solution [3]. Glutathione is present in almost all cells at millimolar concentrations and can detoxify some transition-metal ions.

In this work, we have applied nanoscale liquid chromatography-Fourier transform ion cyclotron mass spectrometry (nanoLC-FTICR MS) to identify these clusters and ${ }^{18} \mathrm{OH}_{2}$ derivatization to determine whether oxygen from solvent becomes incorporated into oxidized glutathione found in the products.

\section{Experimental}

Materials

$\left[\left(\eta \eta^{6}\right.\right.$-bip) RuCl(en)][PF $]$ (1) was synthesized as described elsewhere $[10,11]$. Glutathione (GSH, reduced) and disodium hydrogen phosphate were purchased from Sigma (Dorset, UK), sodium dihydrogen phosphate from Aldrich (Dorset, UK), trifluoroacetic acid (TFAH) from Acros (Geel, Belgium) (Andover, MA) ${ }^{18} \mathrm{O}$-labeled 


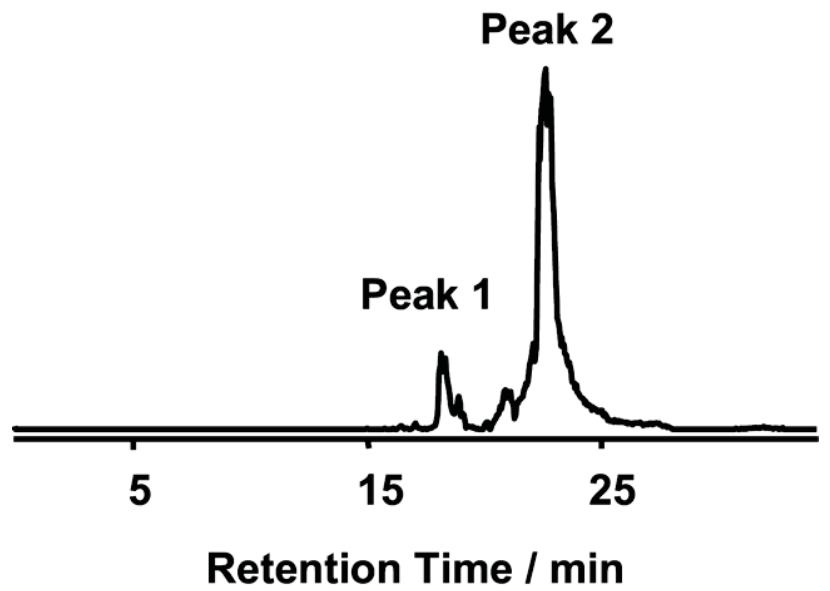

Figure 1. Chromatogram with TIC detection for the reaction of $\left[\left(\eta^{6} \text {-bip }\right) \mathrm{Ru}(\mathrm{en}) \mathrm{Cl}\right]^{+}$with GSH 2:20 $\mathrm{mM}$ in unbuffered solution $(\mathrm{pH} \sim 3)$ at $310 \mathrm{~K}$ for $48 \mathrm{~h}$.

water $\left(95 \% \mathrm{H}_{2}{ }^{18} \mathrm{O}\right)$ from Cambridge Isotope Laboratories (Andover, MA).

\section{Instrumentation}

Positive-ion electrospray ionization mass spectra were obtained with a Bruker APEX III FT-ICR mass spectrometer (Bruker Daltonics, Billerica, MA) equipped with a 9.4 tesla actively shielded superconducting magnet (Magnex, UK). The instrument was modified inhouse by the replacement of the glass capillary with a heated metal transfer capillary held at a temperature of $423 \mathrm{~K}$ and a potential of $50 \mathrm{~V}$. Ions were accumulated in an RF-only hexapole ion storage region for $2 \mathrm{~s}(1.2 \times$ $10^{-7}$ mbar), before being transferred into the "infinity" cell $\left(1.5 \times 10^{-11}\right.$ mbar $)$ using "sidekick" trapping. An UltiMate 3000 series system (Dionex, UK) with nanoflow splitter was coupled to the mass spectrometer using an TriVersa NanoMate (Advion, Ithaca, NY) with an electrospray potential of $1.7 \mathrm{kV}$. Mobile phase A: water (for LC-MS application, Fisher Chemicals) containing $2 \% \mathrm{CH}_{3} \mathrm{CN}$ and $0.1 \%$ TFAH; mobile phase $\mathrm{B}: \mathrm{CH}_{3} \mathrm{CN}$ (for LC-MS application, Fisher Chemicals, oughborough, UK) containing $20 \%$ water and $0.1 \%$ TFAH. The sample was trapped and washed for $3 \mathrm{~min}$ at $30 \mu \mathrm{L}$ $\min ^{-1}$ on a $\mu$-Precolumn $(300 \mu \mathrm{m} \times 5 \mathrm{~mm}, 5 \mu \mathrm{m}, 100$ $\AA$ ). The sample was eluted onto an analytical PepMap 100 column $(75 \mu \mathrm{m} \times 15 \mathrm{~cm}, 3 \mu \mathrm{m}, 100 \AA)$ held in a column-oven at $303 \mathrm{~K}$. The flow rate was $300 \mathrm{~nL}$ $\min ^{-1}$, and gradient (Solvent B) was as follows: 0 to $30 \%$ until $23 \mathrm{~min}, 30$ to $100 \%$ from 23 to $24 \mathrm{~min}, 100 \%$ from 24 to $27 \mathrm{~min}, 100$ to $0 \%$ from 27 to $29 \mathrm{~min}$, and reset to $0 \%$ until $30 \mathrm{~min}$. All spectra were acquired using XMass 7.02 (Bruker Daltonics) with $512 \mathrm{k}$ data points in the range $90-3000 \mathrm{~m} / \mathrm{z}$. Bruker Daltonics Data Analysis software was used for analysis and post processing.

\section{Results and Discussion}

In unbuffered solution ( $\mathrm{pH}$ ca. 3) and at $310 \mathrm{~K}$, the ruthenium arene anticancer complex $\left[\left(\eta^{6}\right.\right.$-bip $)$ $\mathrm{Ru}(\mathrm{en}) \mathrm{Cl}^{+}(\mathbf{1})$ reacted with 10 mol equivalent glutathione ( $\gamma$-L-Glu-L-Cys-Gly, GSH) to give two di-ruthenium glutathione complexes as the main products (Figure S1, which can be found in the electronic version of this article), of which the di-ruthenium triply-S bridged product centered at $13.99 \mathrm{~min}$ has been identified previously by conventional LC-ESI MS and NMR [3]. The ESI-Q MS showed that the fraction centered at 17.25 min contains a di-ruthenium glutathione sulfenate/ sulfinate complex (Figures S1 and S2). However, the concentration of multinuclear ruthenium clusters in the fraction eluted from 10.93 to $12.24 \mathrm{~min}$ was too low to allow good ESI MS analysis (Figures S1 and S2). The fraction centered at 17.25 min was also collected and

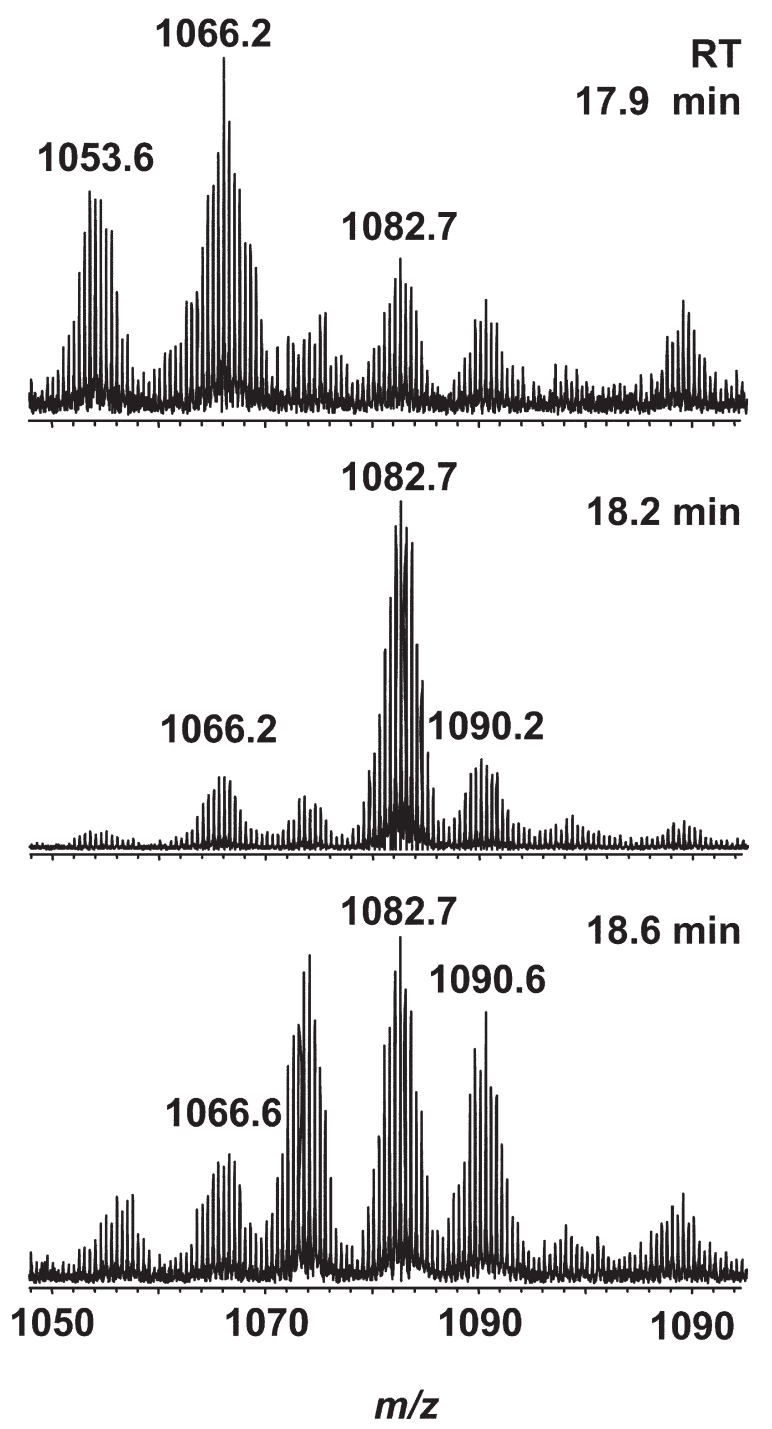

Figure 2. Mass spectra for fractions corresponding to LC peak 1 (retention times of 18.6, 18.2, and $17.9 \mathrm{~min}$, Figure 1) for the reaction of $\left[\left(\eta^{6} \text {-bip) } \mathrm{Ru}(\mathrm{en}) \mathrm{Cl}\right]^{+}\right.$and GSH 2:20 $\mathrm{mM}$ in water $(\mathrm{pH} \sim$ 3) at $310 \mathrm{~K}$ for $48 \mathrm{~h}$. 


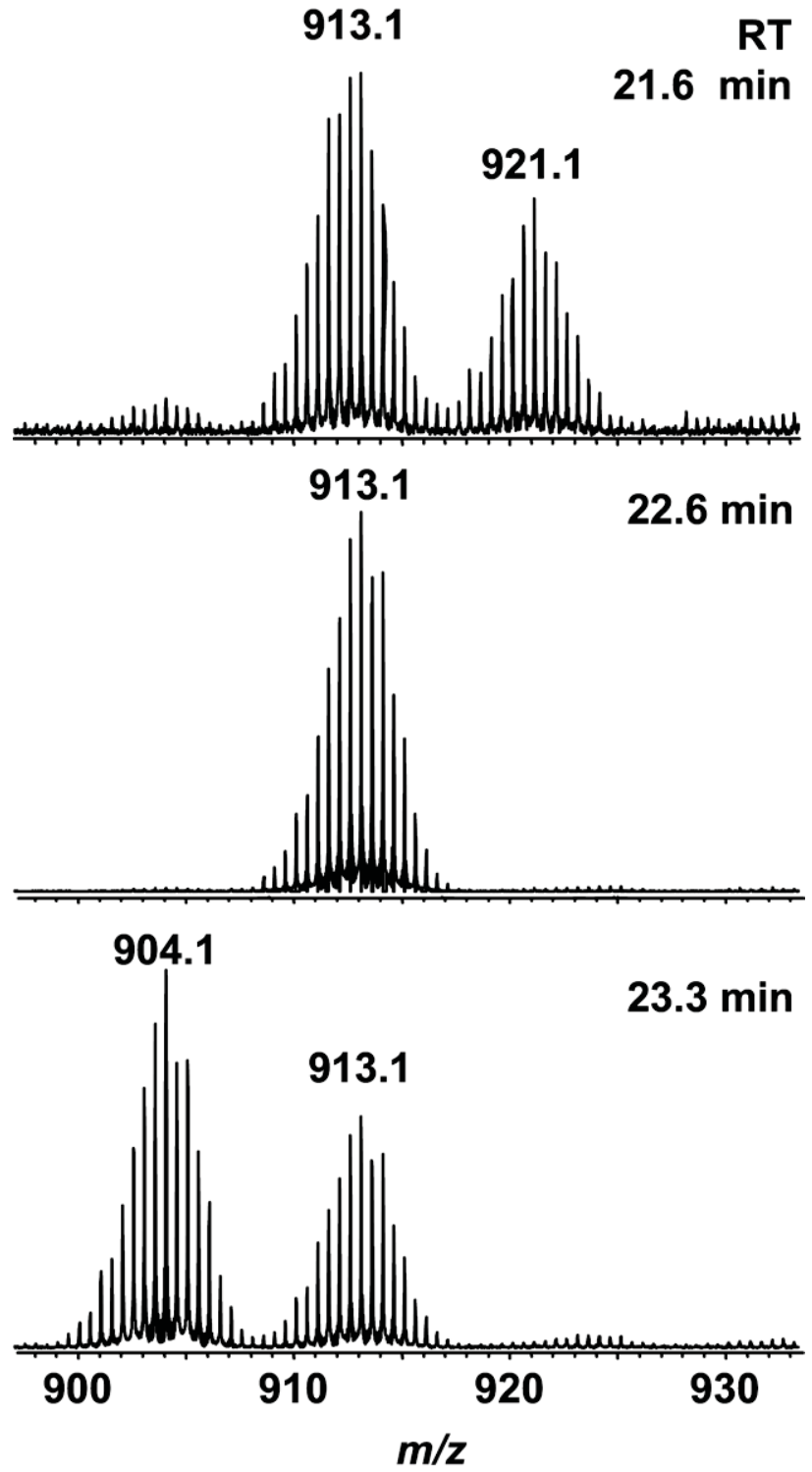

Figure 3. Mass spectra for fractions corresponding to LC peak 2 (retention times 23.3, 22.6, and 21.6, see Figure 1) from the reaction of $\left[\left(\eta^{6} \text {-bip }\right) \mathrm{Ru}(\mathrm{en}) \mathrm{Cl}\right]^{+}$and $\mathrm{GSH} 2: 20 \mathrm{mM}$ in water $(\mathrm{pH} \sim 3)$ at 310 $\mathrm{K}$ for $48 \mathrm{~h}$.

concentrated for ESI-Q MS and NMR experiments. NMR results (Figure S3) show that only one set of proton resonances is observed for the two biphenyl ligands, suggesting that the two ruthenium centers in this complex are equivalent. No resonances are observed for the protons of the chelated ethylenediamine(en) ligand, indicating that the en ligands have been displaced from ruthenium by oxidized GSH ligands (Figure S3). The NMR sample was diluted with 1:1 $\mathrm{H}_{2} \mathrm{O} / \mathrm{CH}_{3} \mathrm{CN}$ and analyzed by ESI-Q MS with various cone voltages in an attempt to obtain further structural information. However, the low-resolution of the mass spectra did not allow unambiguous identification of the di-ruthenium product either, although several fragmented ions observed with a cone voltage of $50 \mathrm{~V}$
(Figure S4) appeared to correspond to the release of one and two sulfinate $\left(\mathrm{GSO}_{2}\right)$ ligands from the parent di-ruthenium complexes.

The di-ruthenium product was also detectable in the reaction mixture of complex $\mathbf{1}$ with GSH under argon and physiologically-relevant conditions (Ru:GSH 0.02:5 $\mathrm{mM}$, in $22 \mathrm{mM} \mathrm{NaCl}, \mathrm{pH} 7$ at $310 \mathrm{~K}$ for 48 h; Figure S5). Since the glutathione adduct may be involved in the biological mechanism of action of this ruthenium arene anticancer complex, ESI-FT-ICR MS experiments were performed to identify the adducts.

To identify unambiguously the multinuclear ruthenium glutathione product by MS, $5 \mu \mathrm{L}$ of a reaction mixture of higher concentration of complex 1 with GSH $(2: 20 \mathrm{mM})$ in unbuffered aqueous solution was incubated at $310 \mathrm{~K}$ for $48 \mathrm{~h}$ and separated by a nanoscale $\mathrm{C} 18$ reverse phase $\mathrm{LC}$. The eluent was introduced to the ESI-FT-ICR MS using the nanoMate. Two TIC peaks were observed as shown in Figure 1. The partial mass

(a)

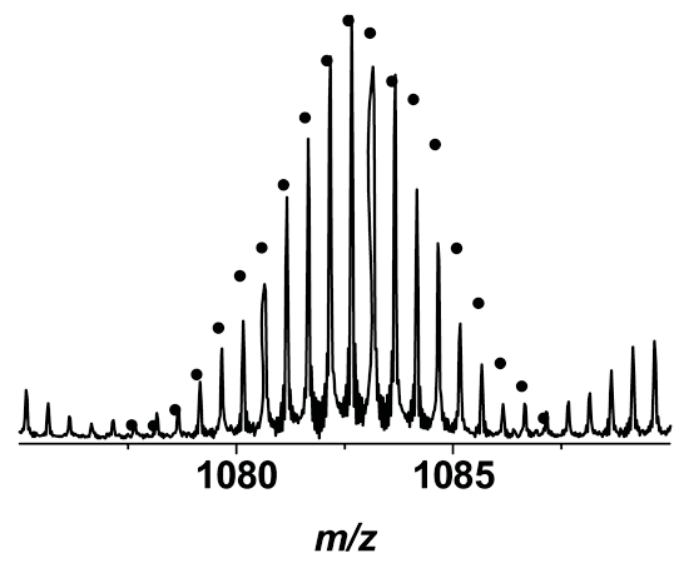

(b)

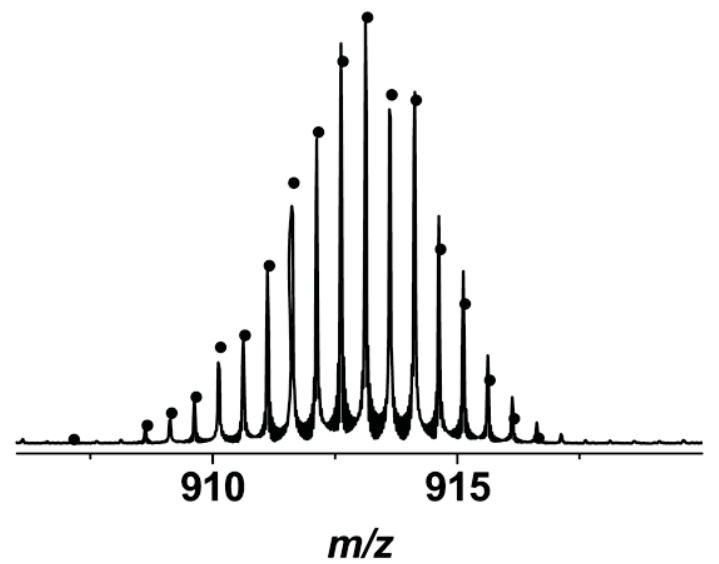

Figure 4. Isotopic models (dots, for which the values of $x$ and $y$ correspond to the $\mathrm{m} / \mathrm{z}$ value and intensity of the respective isotopic ion peak) and mass spectra (lines) for fragment ions of arene ruthenium sulfinate glutathione adducts: (a) $\left\{\left[\left(\eta^{6} \text {-bip }\right) \mathrm{Ru}\left(\mathrm{GSO}_{2}\right)\right]_{4}-\right.$ Glu $-5 \mathrm{O}+4 \mathrm{H}\}^{2+}\left(\left[\mathrm{C}_{83} \mathrm{H}_{96} \mathrm{O}_{24} \mathrm{~S}_{4} \mathrm{~N}_{11} \mathrm{Ru}_{2}{ }_{2} \mathrm{Ru}_{2}\right]^{2+}\right)$ and (b) $\left\{\left[\left(v^{6}-\right.\right.\right.$ bip) $\left.\left.\mathrm{Ru}\left(\mathrm{GSO}_{2}\right)_{2}\right]_{2}-3 \mathrm{O}+10 \mathrm{H}\right\}^{2+}\left(\left[\mathrm{C}_{64} \mathrm{H}_{92} \mathrm{O}_{29} \mathrm{~S}_{4} \mathrm{~N}_{12} \mathrm{Ru}_{2}^{0}\right]^{2+}\right)$. Possible structures for the adducts are shown in Chart 2. 
(a)<smiles>[As]</smiles>

(b)<smiles></smiles>

Chart 1. (a) $\mathrm{GS}(\mathrm{O}) \mathrm{H}$ (glutathione sulfenic acid) and (b) $\mathrm{GS}(\mathrm{O})_{2} \mathrm{H}$ (glutathione sulfinic acid). As ligands for ruthenium, the sulfur atom is deprotonated and at neutral $\mathrm{pH}$ then carries an overall charge of $2-$ for both sulfenate (GSO) and sulfinate $\left(\mathrm{GSO}_{2}\right)$ groups.

spectra for the fractions at specific retention times are shown in Figures 2 and 3, and the full scan spectra for the fractions eluting at 17.2 and $22.6 \mathrm{~min}$ in Figures S6 and S7. For the fractions of the first LC peak, a series of doubly charged ions is detected within the range $\mathrm{m} / \mathrm{z}$ $1050-1110$, with a mass difference between the neighboring ion clusters of $16 \mathrm{Da}$, i.e., an $\mathrm{O}$ atom (Figure 2). Corresponding to the doubly charged ion centered at $\mathrm{m} / \mathrm{z} 1083.6502$ for the fraction eluting at $17.2 \mathrm{~min}$, a triply charged ion centered at $\mathrm{m} / \mathrm{z} 722.4247$ was observed (Figure S6). Similarly, a series of doubly charged ion peaks is detected within the range 900-930 for the fractions of the second LC peak; the difference between the neighboring ion clusters is also $16 \mathrm{Da}$, indicative of the loss or gain of an $\mathrm{O}$ atom between them (Figure 3). The full scan spectrum (Figure S7) for the fraction eluting at $22.6 \mathrm{~min}$ shows a triply charged ion centered at $m / z 1217.1663$ assignable to the dimer of the doubly charged ion centered at $\mathrm{m} / \mathrm{z} 913.1206$.

FT-ICR MS has previously been applied to the unambiguous determination of the oxidation state of iron in a metalloprotein by matching experimental and theoretical isotopic abundance mass distribution [12]. The isotopic simulations shown in Figure 4 suggest that the two LC peaks contain mixtures of tetra- and di-ruthenium sulfinate/sulfenate $\left(\mathrm{GSO}_{2} \mathrm{H} / \mathrm{GSOH}\right.$ see Chart 1) glutathione complexes, respectively. The possible structures for the two main species are shown in Chart 2.The isotopic simulations (Figure 4) suggest that in the tetra-ruthenium adduct, two of the $\mathrm{Ru}^{\mathrm{II}}$ ions from the starting complex may be reduced to $\mathrm{Ru}^{\mathrm{I}}$, and in the di-ruthenium complex, both of the $\mathrm{Ru}^{\mathrm{II}}$ ions may be reduced to $\mathrm{Ru}^{0}$. The biphenyl proton signals in the ${ }^{1} \mathrm{H}$ NMR spectrum shown in Figure S8 for the fraction eluting from 10.90 to $12.50 \mathrm{~min}$ are too broad to observe, appearing to support the possibility that the ruthenium atoms in this cluster may be oxidized from $\mathrm{Ru}^{\mathrm{II}}$ to $\mathrm{Ru}^{\mathrm{I}}$, which is paramagnetic (although partial or complete spin-pairing is possible). The IR spectra of both of the adducts showed two bands at 855 and $920 \mathrm{~cm}^{-1}$, evidence for the formation of $\mathrm{S}-\mathrm{O}$ single bonds in $\mathrm{S}-\mathrm{O}-\mathrm{H}$ or $\mathrm{S}-\mathrm{O}-\mathrm{M}$ models. These data will stimulate further investigations of the nature of the postulated $\mathrm{Ru}-\mathrm{Ru}, \mathrm{Ru}-\mathrm{S}, \mathrm{Ru}-\mathrm{S}-\mathrm{Ru}$, and Ru-S-O-Ru bonds, as well as the oxidation state of $\mathrm{Ru}$ [e.g., by X-ray absorption analysis].

The apparent stabilization of low oxidation states of ruthenium by oxidized sulfur ligands is surprising but may be aided by the formation of strong hydrogen bonds involving sulfinato oxygens under the acidic conditions used for chromatography and mass spectrometry $(0.1 \%$ TFAH in the mobile phase) as has been reported for $\mathrm{Ni}^{\mathrm{II}} / \mathrm{Ni}^{\mathrm{I}}$ in the nickel sulfinate/sulfenate complexes [13]. The presence of $\mathrm{Ru}^{\mathrm{II}}$ and hydride ligands (shift of two electrons from $\mathrm{Ru}^{0}$ or $2 \mathrm{Ru}^{\mathrm{I}}$ to $\mathrm{H}^{+}$) cannot readily be ruled out since $\mathrm{Ru}^{\mathrm{II}}$ is known to form stable hydride complexes. However no ${ }^{1} \mathrm{H}$ NMR
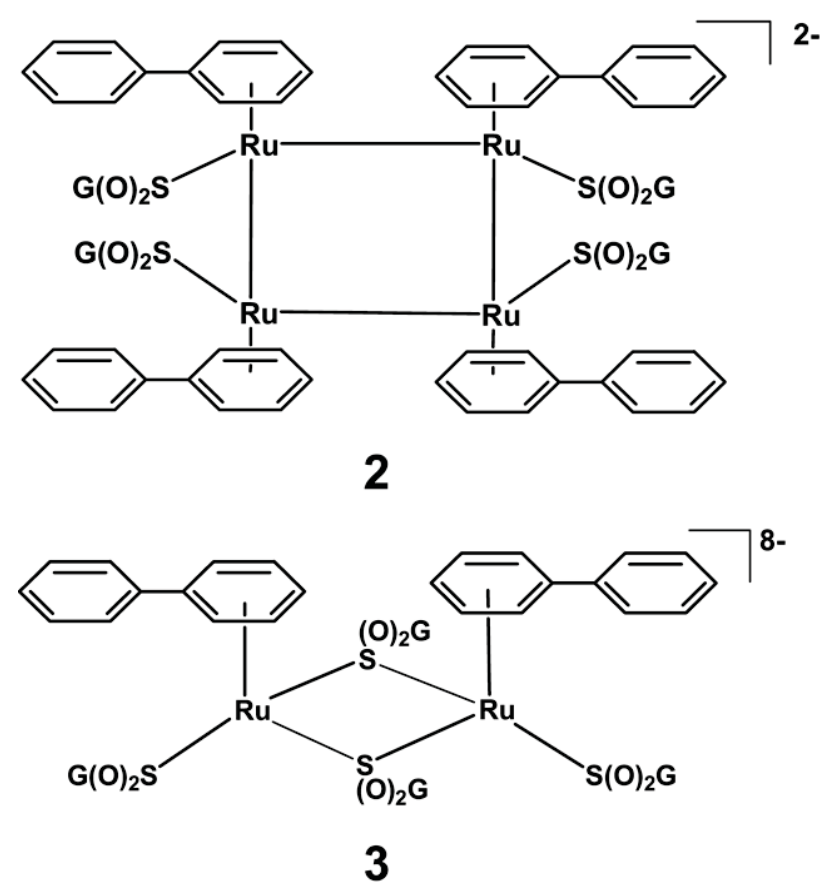

Chart 2. Proposed structures of tetra- and di-ruthenium glutathione sulfinate adducts. The exact nature of the bridges between the ruthenium atoms in these clusters is unknown. In the presence of TFAH $(0.1 \%)$ in the mobile phase, the two carboxylate groups and one SO group in the glutathione sulfinate ligands can be protonated to give $\mathrm{H}_{2} \mathrm{GSO}_{2} \mathrm{H}$ ligands which carry charges of $1+$. 
Table 1. The mass-to-charge ratios of the most abundant isotopomer of the ion fragments from the ruthenium sulfinate/ sulfenate glutathione adducts $\left[\left\{\left(\eta^{6}-\text { bip }\right) \mathrm{Ru}\left(\mathrm{GSO}_{2}\right)\right\}_{4}\right]^{2-}$ (2) and $\left[\left\{\left(\eta^{6} \text {-bip }\right) \mathrm{Ru}\left(\mathrm{GSO}_{2}\right)_{2}\right\}_{2}\right]^{8-}$ (3) detected by direct infusion ESI-FT-ICR MS

\begin{tabular}{rrl}
\hline Adduct $^{\mathrm{a}}$ & $\mathrm{m} / \mathrm{z}$ (obs) & \multicolumn{1}{c}{ Ion } \\
\hline \hline $\mathbf{2}$ & 722.4247 & $\left\{\mathbf{2}-\mathrm{Glu}^{\mathrm{b}}-5 \mathrm{O}+5 \mathrm{H}^{\mathrm{c}}\right\}^{3+}$ \\
781.7766 & $\{\mathbf{2}-2 \mathrm{O}+5 \mathrm{H}\}^{3+}$ \\
787.1078 & $\{\mathbf{2}-\mathrm{O}+5 \mathrm{H}\}^{3+}$ \\
792.4406 & $\{\mathbf{2}+5 \mathrm{H}\}^{3+}$ \\
1083.6502 & $\{\mathbf{2}+4 \mathrm{H}-\mathrm{Glu}-5 \mathrm{O}\}^{2+}$ \\
1094.1453 & $\{\mathbf{2}+4 \mathrm{H}-\mathrm{Glu}-4 \mathrm{O}\}^{2+}$ \\
1103.6351 & $\{\mathbf{2}+4 \mathrm{H}-\mathrm{Glu}-3 \mathrm{O}\}^{2+}$ \\
1108.1169 & $\{\mathrm{unknown}\}^{3+}$ \\
1173.1748 & $\{\mathbf{2}+4 \mathrm{H}-2 \mathrm{O}\}^{2+}$ \\
1181.1743 & $\{\mathbf{2}+4 \mathrm{H}-\mathrm{O}\}^{2+}$ \\
1189.1709 & $\{\mathbf{2}+4 \mathrm{H}\}^{2+}$ \\
5556.7662 & $\{\mathbf{3}-\mathrm{Glu}-\mathrm{Gly}+11 \mathrm{H}\}^{3+}$ \\
565.7668 & $\{\mathbf{3}-\mathrm{Glu}-3 \mathrm{O}+11 \mathrm{H}\}^{3+}$ \\
609.1334 & $\{\mathbf{3}-3 \mathrm{O}+11 \mathrm{H}\}^{3+}$ \\
665.0882 & $\left\{\mathbf{3}-\mathrm{Glu}-\mathrm{Gly}-\mathrm{GSO} \mathrm{F}_{2}+10 \mathrm{H}\right\}^{2+}$ \\
& 834.6312 & $\{\mathbf{3}-\mathrm{Glu}-\mathrm{Gly}+10 \mathrm{H}\}^{2+}$ \\
848.1573 & $\{\mathbf{3}-\mathrm{Glu}-3 \mathrm{O}+10 \mathrm{H}\}^{2+}$ \\
& 913.1215 & $\{\mathbf{3}-3 \mathrm{O}+10 \mathrm{H}\}^{2+}$ \\
$\mathbf{3}$ &
\end{tabular}

${ }^{a}$ For proposed structures of adducts see Chart 2 and for mass spectra see Figures S9 and S10.

bIndicates loss of a Glu residue $\mathrm{HO}_{2} \mathrm{CCH}\left(\mathrm{NH}_{2}\right) \mathrm{CH}_{2} \mathrm{CH}_{2} \mathrm{CO}\left(\mathrm{C}_{5} \mathrm{H}_{8} \mathrm{O}_{3} \mathrm{~N}\right)$.

${ }^{\mathrm{C}} \mathrm{H}$ indicates gain of a proton.

dindicates loss of a Gly residue $\mathrm{NHCH}_{2} \mathrm{CO}_{2} \mathrm{H}\left(\mathrm{C}_{2} \mathrm{H}_{4} \mathrm{O}_{2} \mathrm{~N}\right)$.

peaks characteristic of hydride ligands (with negative chemical shifts) were detected. Also different species may be stabilized in the gas phase after desolvation than in solution.

The two fractions separated from the reaction mixture of complex 1 with GSH (2:20 mM) were collected using conventional HPLC and analyzed by ESI-FT-ICR MS. A series of doubly- and triply charged ions was observed and their $\mathrm{m} / \mathrm{z}$ values and assignments are listed in Table 1; the mass spectra are shown in Figures S9 and S10. The results agree with the nanoLC-MS measurements, confirming that the first LC peak, shown in Figure 1, is a mixture of tetra-ruthenium glutathione sulfinate/sulfenate complexes, and the second, a mixture of di-ruthenium glutathione sulfinate/ sulfenate complexes.

Our previous work has shown that the monoruthenium thiolate adduct formed from the reaction of complex 1 with GSH under physiologically-relevant conditions as described above is readily oxidized to the sulfenate adduct in the presence of $\mathrm{O}_{2}$ [3]. However, under argon, the same reaction gave rise to a small amount of the di-ruthenium sulfinate adduct as shown in Figure S5, implying that, under these conditions, water may be involved as an oxygen donor during formation of the oxidized thiolate ligands in the ruthenium glutathione adducts, perhaps with accompanying reduction of $\mathrm{Ru}^{\mathrm{II}}$. Next we used isotopic labeling to test whether oxygen from solvent water can become incorporated into the sulfenate/sulfinate ligands in the products.
A reaction mixture of complex 1 with GSH (2:20 mM) in unbuffered $66.6 \%{ }^{18} \mathrm{O}$-labeled water incubated at 310 $\mathrm{K}$ for $48 \mathrm{~h}$ was analyzed using the nanoLC-nanoESI-FTICR MS method described above. Two peaks similar to those shown in Figure 1 appeared in the TIC chromatogram (data not shown). The partial mass spectra of the fractions eluting at 18.2 and $22.6 \mathrm{~min}$ are shown in Figure 5, and the full scan spectra in Figures S11 and S12. For the first fraction, a doubly charged ion centered at $m / z 1084.6487$ and a triply charged ion centered at $m / z$ 723.4261 (Figure 5 and Figure S11) were detected. Apart from the doubly charged ion centered at $\mathrm{m} / \mathrm{z} 915.1388$ and the triply charged ion at $m / z$ 1219.1722, a quadruply charged ion centered at $m / z 1371.6784$ became detectable for the second fraction eluting at $22.6 \mathrm{~min}$ (Figure 5 and Figure S12), which appears to correspond to a trimer of the doubly charged ion at $m / z$ 915.1388. The isotopic simulations (Figure 6) indicate that the two fractions contain tetra- and di-ruthenium glutathione sulfinate/sulfenate complexes, respectively, for which the oxygen atoms in the sulfinate and sulfenate ligands contain ${ }^{18} \mathrm{O}$ and therefore arise from solvent water.

\section{Conclusions}

The glutathione adduct of the anticancer complex $\left[\left(\eta^{6}-\right.\right.$ bip) $\mathrm{Ru}(\mathrm{en}) \mathrm{Cl}]^{+}$readily undergoes oxidation of coordinated glutathione to give rise to two multinuclear
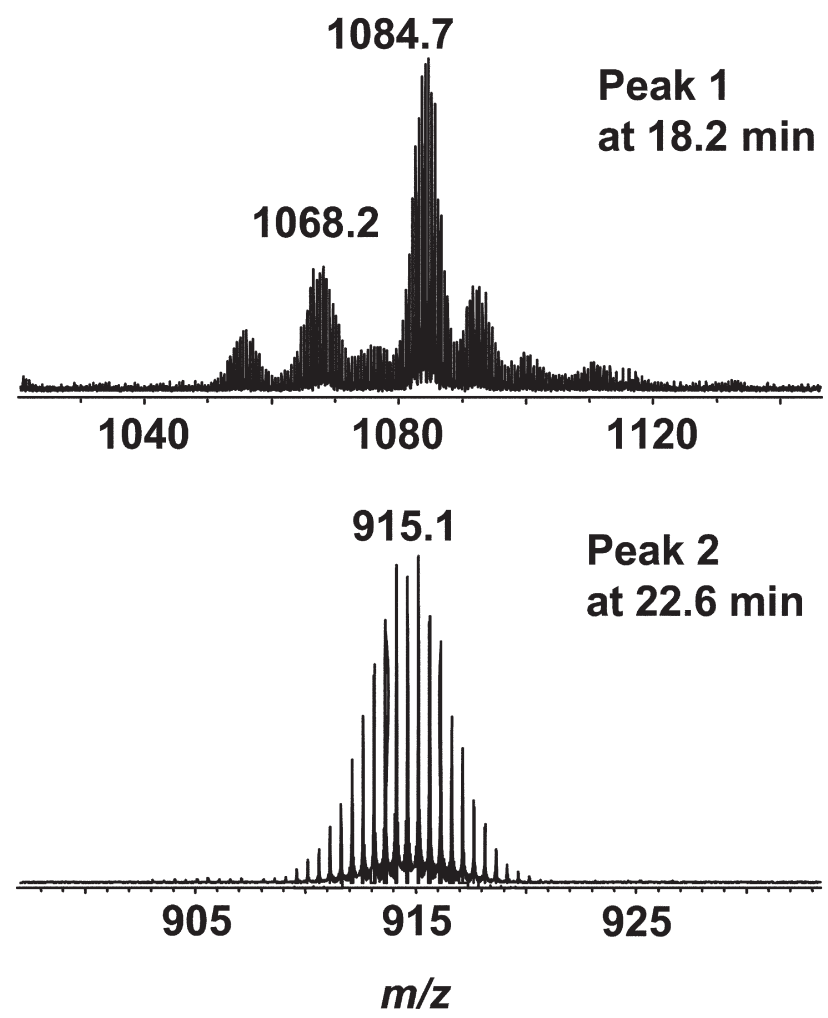

Figure 5. Mass spectra for fractions corresponding to LC peaks 1 and 2 from the reaction of $\left[\left(\eta^{6} \text {-bip }\right) \mathrm{Ru}(\mathrm{en}) \mathrm{Cl}\right]^{+}$and GSH 2:20 mM in $66.6 \%{ }^{18} \mathrm{O}$-labeled water $(\mathrm{pH} \sim 3)$ at $310 \mathrm{~K}$ for $48 \mathrm{~h}$. 
(a)

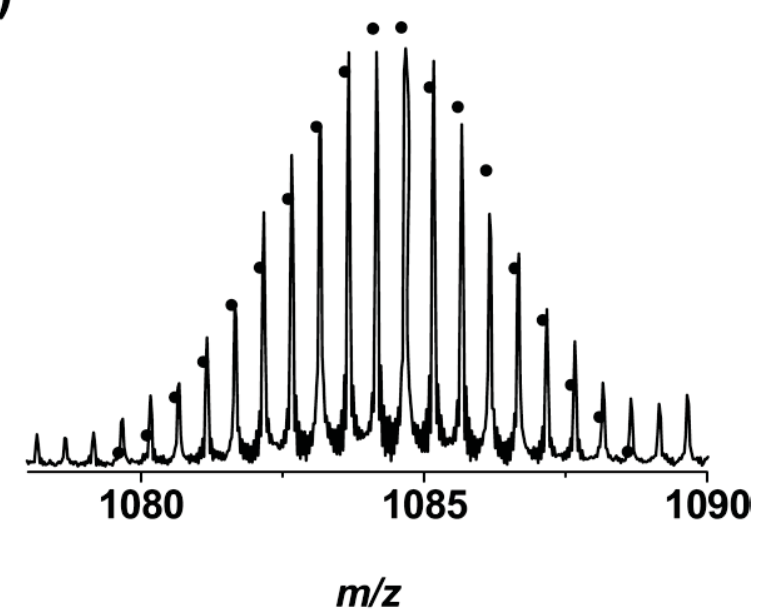

(b)

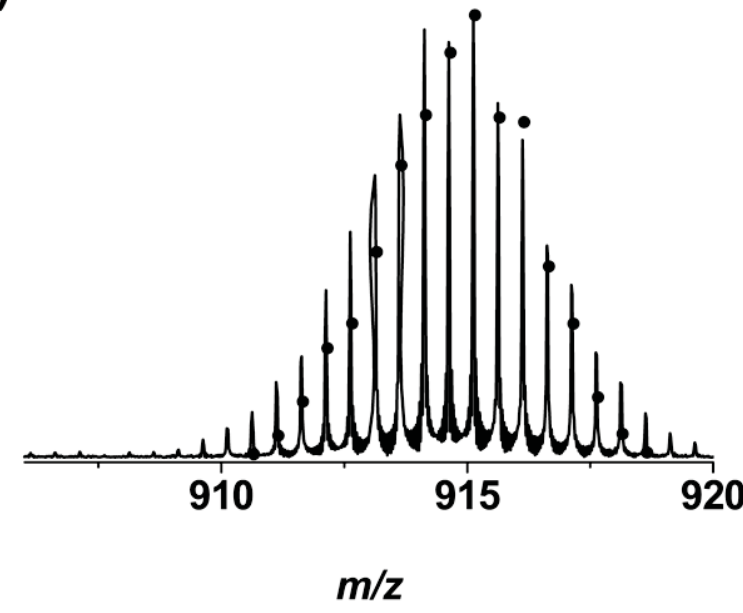

Figure 6. Isotopic model (dots, for which the values of $x$ and $y$ correspond to the $\mathrm{m} / \mathrm{z}$ and intensity of the respective isotopic ion peak), and mass spectra (lines) for fragment ions of arene ruthenium ${ }^{18} \mathrm{O}$-labeled glutathione sulfinate adducts. (a) $\left\{\left[\left(\eta^{6}\right.\right.\right.$-bip) $\left.\left.\mathrm{Ru}\left(\mathrm{GS}^{18} \mathrm{O}_{2}\right)\right]_{4}-\mathrm{Glu}-5^{18} \mathrm{O}+4 \mathrm{H}\right\}^{2+}\left(\left[\mathrm{C}_{83} \mathrm{H}_{96} \mathrm{O}_{21}{ }^{18} \mathrm{O}_{3} \mathrm{~S}_{4} \mathrm{~N}_{11} \mathrm{Ru}^{\mathrm{II}}{ }_{2}\right.\right.$ $\left.\left.\mathrm{Ru}_{2}^{\mathrm{I}}\right]^{2+}\right)$ and (b) $\left\{\left[\left(\eta^{6} \text {-bip) } \mathrm{Ru}\left(\mathrm{GS}^{18} \mathrm{O}_{2}\right)_{2}\right]_{2-} 3^{18} \mathrm{O}+10 \mathrm{H}\right\}^{2+}\right.$ $\left(\left[\mathrm{C}_{64} \mathrm{H}_{92} \mathrm{O}_{24}{ }^{18} \mathrm{O}_{5} \mathrm{~S}_{4} \mathrm{~N}_{12} \mathrm{Ru}_{2}^{0}\right]^{2+}\right)$. Possible structures for the adducts are shown in Chart 2.

complexes as the main products. These were unambiguously identified as di-ruthenium and tetra-ruthenium glutathione sulfinate complexes. The MS data suggest that the initial $\mathrm{Ru}^{\mathrm{II}}$ may have undergone reduction to give $\mathrm{Ru}^{\mathrm{I}}$ and $\mathrm{Ru}^{0}$ in these products. This possibility will stimulate further work to elucidate the oxidation state of ruthenium in these adducts and their coordination geometries. With ${ }^{18} \mathrm{O}$-labeled water as solvent, FT-ICR MS analysis indicated that oxygen atoms in sulfenate and sulfinate products can arise from water, implying that water can be involved in oxygen atom insertion into $\mathrm{S}-\mathrm{O}$ bonds in the sulfenate and sulfinate ligands. Interestingly, the $\mathrm{S}-\mathrm{O}$ bonds in cysteinyl sulfenate/ sulfinate ligands in enzymes are thought to be involved in oxygen atom insertion into substrates and in biological signaling processes [14-18]. This work illustrates the power of FTMS coupled with nanoscale liquid chromatography and isotopic labeling for elucidating pathways for reactions of metallodrugs with intracellular biomolecules.

\section{Acknowledgments}

The authors thank RCUK (Interdisciplinary Research Centre RASOR), the Chinese Academy of Sciences, and Oncosense Ltd. for support, Dr. Holm Petzold (University of Edinburgh) for helpful discussion, and ORS for a scholarship for JX.

\section{References}

1. Yan, Y.-K.; Melchart, M.; Habtemariam, A.; Sadler, P. J. Organometallic Chemistry, Biology, and Medicine: Ruthenium Arene Anticancer Complexes. Chem. Commun. 2005, 4764-4776.

2. Wang, F. Y.; Chen, H. M.; Parkinson, J. A.; Murdoch, P. D.; Sadler, P. J Reactions of a Ruthenium(II) Arene Antitumor Complex with Cysteine and Methionine. Inorg. Chem. 2002, 41, 4509-4523.

3. Wang, F. Y.; Xu, J. J.; Habtemariam, A.; Bella, J.; Sadler, P. J. Competition Between Glutathione and Guanine for a Ruthenium(II) Arene Anticancer Complex: Detection of a Sulfenato Intermediate. J. Am. Chem. Soc. 2005, 127, 17734-17743.

4. Dyson, P. J.; Johnson, B. F. G.; McIndoe, J. S.; Langridge-Smith, P. R. R. Application of Laser Desorption and Electrospray Ionization Mass Spectrometry at the Transition Between Clusters and Colloids. Inorg. Chem. 2000, 39, 2430-2431.

5. Butcher, C. P. G.; Dinca, A.; Dyson, P. J.; Johnson, B. F. G.; LangridgeSmith, P. R. R.; McIndoe, J. S. A Strategy for Generating Naked-Metal Clusters for Gas-Phase Reactivity Studies by FTICR-MS. Angew. Chem. Int. Ed. 2003, 42, 5752-5755.

6. Dyson, P. J.; Hearley, A. K.; Johnson, B. F. G.; Khimyak, T.; McIndoe, J. S.; Langridge-Smith, P. R. R. Mass Spectrometric Method for the Rapid Characterization of Transition Metal Carbonyl Cluster Reaction Mixtures. Organometallics 2001, 20, 3970-3974.

7. Wang, F.; Chen, H. M.; Parsons, S.; Oswald, L. D. H.; Davidson, J. E.; Sadler, P. J. Kinetics of Aquation and Anation of Ruthenium(II) Arene Anticancer Complexes, Acidity, and X-Ray Structures of Aqua Adducts. Chem. Eur. J. 2003, 9, 5810-5820.

8. Wang, F. Y.; Bella, J.; Parkinson, J. A.; Sadler, P. J. Competitive Reactions of a Ruthenium Arene Anticancer Complex with Histidine, Cytochrome c, and an Oligonucleotide. J. Biol. Inorg. Chem. 2005, 10, 147-155.

9. Wang, F. Y.; Habtemariam, A.; van der Geer, E. P. L.; Fernandez, R.; Melchart, M.; Deeth, R. J.; Aird, R.; Guichard, S.; Fabbiani, F. P. A.; Lozano-Casal, P.; Oswald, I. D. H.; Jodrell, D. I.; Parsons, S.; Sadler, P. J. Controlling Ligand Substitution Reactions of Organometallic Complexes: Tuning Cancer Cell Cytotoxicity. Proc. Natl. Acad. Sci. U.S.A. 2005, 102, 18269-18274

10. Morris, R. E.; Aird, R. E.; Murdoch, P. D.; Chen, H. M.; Cummings, J.; Hughes, N. D.; Parsons, S.; Parkin, A.; Boyd, G.; Jodrell, D. I.; Sadler, P. J. Inhibition of Cancer Cell Growth by Ruthenium(II) Arene Complexes. J. Med. Chem. 2001, 44, 3616-3621.

11. Chen, H.; Parkinson, J. A.; Parsons, S.; Coxall, R. A.; Gould, R. O.; Sadler, P. J. Organometallic Ruthenium(II) Diamine Anticancer Complexes: Arene-Nucleobase Stacking and Stereospecific HydrogenBonding in Guanine Adducts. I. Am. Chem. Soc. 2002, 124, 3064-3081.

12. He, F.; Hendrickson, C. L.; Marshall, A. G. Unequivocal Determination of Metal Atom Oxidation State in Naked Heme Proteins: Fe(III) Myoglobin, Fe(III) Cytochrome $c$, Fe(III) cytochrome b5, and Fe(III) cytochrome b5 L47R. J. Am. Soc. Mass Spectrom. 2000, 11, 120-126.

13. Farmer, P. J.; Reibenspies, J. H.; Lindahl, P. A.; Darensbourg, M. Y Effects of Sulfur Site Modification on the Redox Potentials of Derivatives of [N,N'-Bis(2-Mercaptoethy1)-1,5-Diazacyclooctanato]nickel(II). J. Am. Chem. Soc. 1993, 115, 4665-4674.

14. Allison, W. S. Formation and Reactions of Sulfenic Acids in Proteins. Acc. Chem. Res. 1976, 9, 293-299.

15. Tsujimura, M.; Odaka, M.; Nakayama, H.; Dohmae, N.; Koshino, H.; Asami, T.; Hoshino, M.; Takio, K.; Yoshida, S.; Maeda, M.; Endo, I. A Novel Inhibitor for Fe-type Nitrile Hydratase: 2-Cyano-2-propyl Hydroperoxide. J. Am. Chem. Soc. 2003, 125, 11532-11538.

16. Lugo-Mas, P.; Dey, A.; Xu, L.; Davin, S. D.; Benedict, J.; Kaminsky, W. Hodgson, K. O.; Hedman, B.; Solomon, E.; Kovacs, J. A. How Does Single Atom Addition Affect the Properties of a Fe-Nitrile Hydratase Analogue? The Compensatory Role of the Unmodified Thiolate. J. Am. Chem. Soc. 2006, 128, 11211-11221.

17. Salmeen, A.; Andersen, J. K.; Mayers, M. P.; Meng, T.-C.; Hinks, J. A.; Tonks, N. K.; Barford, D. Redox Regulation of Protein Tyrosine Phosphatase 1B Involves a Sulphenyl-amide Intermediate. Nature 2003, 423, 769-773.

18. van Montfort, R. L. M.; Congreve, M.; Tisi, D.; Carr, R.; Jhoti, H. Oxidation State of the Active-site Cysteine in Protein Tyrosine Phosphatase 1B. Nature 2003, 423, 773-777. 